\title{
Electron-Structure Calculations and Bond Order Analysis Using Density Functional Theory of Cationic Dinuclear Arene Ruthenium Complexes
}

\author{
Emmanuel Penka Fowe, ${ }^{\dagger}$ Bruno Therrien, ${ }^{\ddagger}$ Georg Suss-Fink, ${ }^{\ddagger}$ and Claude Daul ${ }^{\star, \dagger}$ \\ Institute of Inorganic and Analytical Chemistry, University of Fribourg, Pérolles, CH-1700 \\ Fribourg, Switzerland and Institut de Chimie, Université de Neuchâtel, Case postale 158, \\ CH-2009 Neuchâtel, Switzerland
}

\begin{abstract}
The structure and nature of the metal-metal bonding interaction in the cationic complexes $\left[\left(\eta^{6}-\mathrm{C}_{6} \mathrm{Me}_{6}\right)_{2} \mathrm{Ru}_{2}\left(u_{2^{-}}\right.\right.$ $\left.\mathrm{H})_{3}\right]^{+}(\mathbf{1}),\left[\left(\eta^{6}-\mathrm{C}_{6} \mathrm{Me}_{6}\right)_{2} \mathrm{Ru}_{2}\left(\mu_{2}-\mathrm{H}\right)_{2}\left(\mu_{2}-1,4-\mathrm{SC}_{6} \mathrm{H}_{4} \mathrm{Br}\right)\right]^{+}(2),\left[\left(\eta^{6}-\mathrm{C}_{6} \mathrm{Me}_{6}\right)_{2} \mathrm{Ru}_{2}\left(u_{2}-\mathrm{H}\right)\left(\mu_{2}-1,4-\mathrm{SC}_{6} \mathrm{H}_{4} \mathrm{Br}\right)_{2}\right]^{+}(3)$, and $\left[\left(\eta^{6}-\mathrm{C}_{6}{ }^{-}\right.\right.$ $\left.\left.\mathrm{Me}_{6}\right)_{2} \mathrm{Ru}_{2}\left(\mu_{2}-1,4-\mathrm{SC}_{6} \mathrm{H}_{4} \mathrm{Br}\right)_{3}\right]^{+}(4)$ have been studied at the density functional theory (DFT) level using molecular orbital (MO) theory, bond order (BO) analysis, bond decomposition energy (BDE), electron localization function (ELF), and Laplacian of the density methods. The results show that there is no direct bond between the two ruthenium atoms in 1-4, the MO interaction within the diruthenium backbone being stabilized by the bridging ligands. For complex 1, the ELF clearly shows that the bond within the diruthenium backbone is through the three bridging hydride ligands, which act as a sort of glue by forming three-center two-electron bonds characterized by $(\mathrm{Ru}, \mathrm{H}, \mathrm{Ru}$ ) basins with 1.8 e mostly located in the $\mathrm{H}$ atomic basin.
\end{abstract}

\section{Introduction}

In recent years we have shown that dinuclear cations of the general formula $\left[\left(\eta^{6} \text {-arene }\right)_{2} \mathrm{Ru}_{2}\left(\mu_{2}-\mathrm{H}\right)_{3}\right]^{+}$(arene $=\mathrm{C}_{6}$ $\left.\mathrm{Me}_{6}, 1,2,4,5-\mathrm{C}_{6} \mathrm{H}_{2} \mathrm{Me}_{4}, 1,4-\mathrm{MeC}_{6} \mathrm{H}_{4} \mathrm{Pr}^{\mathrm{i}}, 1,3,5-\mathrm{C}_{6} \mathrm{H}_{3} \mathrm{Me}_{3}, \mathrm{C}_{9} \mathrm{H}_{10}\right)$ possess a great potential for the synthesis of organometallic complexes and clusters. ${ }^{1}$ In particular, these electron-deficient cationic complexes are, in the form of the tetrafluoroborate salts, soluble in water and stable to hydrolysis, which allows their use as building blocks for the synthesis of water-soluble organometallics, Scheme $1 .^{2}$

The first dinuclear cation of the type $\left[\left(\eta^{6} \text {-arene }\right)_{2} \mathrm{M}_{2}\left(\mu_{2^{-}}\right.\right.$ $\left.\mathrm{H})_{3}\right]^{+}$to be reported in the literature was the ruthenium

* To whom correspondence should be addressed. E-mail: claude. daul@unifr.ch.

University of Fribourg.

† Université de Neuchâtel.

(1) (a) Jahncke, M.; Meister, G.; Rheinwald, G.; Stoeckli-Evans, H.; SüssFink, G. Organometallics 1997, 16, 1137. (b) Jahncke, M.; Neels, A.; Stoeckli-Evans, H.; Süss-Fink, G. J. Organomet. Chem. 1998, 565, 97. (c) Jahncke, M.; Neels, A.; Stoeckli-Evans, H.; Süss-Fink, G. J. Organomet. Chem. 1998, 561, 227. (d) Faure, M.; Jahncke, M.; Neels, A.; Stoeckli-Evans, H.; Süss-Fink, G. Polyhedron 1999, 18, 2679. (e) Süss-Fink, G.; Faure, M.; Ward, T. R. Angew. Chem., Int. Ed. 2002, 41, 99. (f) Tschan, M. J.-L.; Chérioux, F.; Therrien, B.; Süss-Fink, G. Eur. J. Inorg. Chem. 2004, 2405. (g) Vieille-Petit, L.; Therrien, B.; Süss-Fink, G. Inorg. Chem. Commun. 2004, 7, 232. (h) Tschan, M. J.-L.; Chérioux, F.; Karmazin-Brelot, L.; Süss-Fink, G. Organometallics 2005, 24, 1974. (i) Therrien, B.; Vieille-Petit, L.; Süss-Fink, G. J. Mol. Struct. 2005, 738, 163. (j) Tschan, M. J.-L.; Süss-Fink, G.; Chérioux, F.; Therrien, B. Chem. Eur. J. 2007, 13, 292.

(2) Süss-Fink, G.; Therrien, B. Organometallics 2007, 26, 766.
Scheme 1. Alternative Representations of the Electron-Deficient Complexes $\left[\left(\eta^{6} \text {-Arene }\right)_{2} \mathrm{Ru}_{2}\left(\mu_{2}-\mathrm{H}\right)_{3}\right]^{+}$with Three $\mathrm{Ru}-\mathrm{H}-\mathrm{Ru}$ Three-Center Bonds or with a Ruthenium-Ruthenium Triple Bond

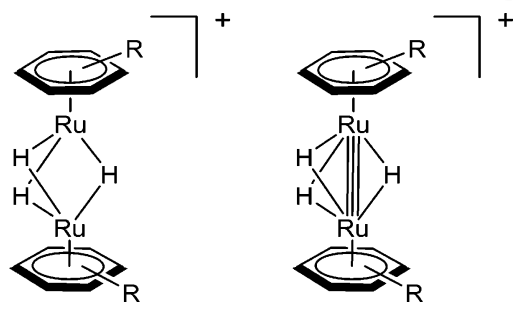

complex $\left[\left(\eta^{6}-\mathrm{C}_{6} \mathrm{Me}_{6}\right)_{2} \mathrm{Ru}_{2}\left(\mu_{2}-\mathrm{H}\right)_{3}\right]^{+}$, which has been obtained by $\mathrm{M}$. Bennett et al. from the reaction of $\left[\left(\eta^{6}-\mathrm{C}_{6} \mathrm{Me}_{6}\right)_{2} \mathrm{Ru}_{2^{-}}\right.$ $\left.\left(\mu_{2}-\mathrm{H}\right)\left(\mu_{2}-\mathrm{Cl}\right)_{2}\right]^{+}$with $\mathrm{NaBH}_{4}$ in ethanol and isolated as the hexafluorophosphate salt, reported to be a dark green-gray material; it was only characterized by the ${ }^{1} \mathrm{H}$ NMR signal of the three equivalent hydrido ligands, and no yield was given. ${ }^{3}$ Ten years later, a more reliable synthesis was published involving the reaction of a mononuclear complex of the empirical formula $\left[\left(\eta^{6}-\mathrm{C}_{6} \mathrm{Me}_{6}\right) \mathrm{Ru}\left(\mathrm{OSO}_{2} \mathrm{CF}_{3}\right)_{2}\right] \cdot 2 \mathrm{H}_{2} \mathrm{O}$ with isopropanol and anhydrous sodium carbonate followed by reaction with sodium hexafluorophosphate: The salt $\left[\left(\eta^{6}-\right.\right.$ $\left.\left.\mathrm{C}_{6} \mathrm{Me}_{6}\right)_{2} \mathrm{Ru}_{2}\left(\mu_{2}-\mathrm{H}\right)_{3}\right]\left[\mathrm{PF}_{6}\right]$-now reported to be a light brown solid-as well as the corresponding chloride and triflate salts and the durene analogues $\left[\left(\eta^{6}-1,2,4,5-\mathrm{C}_{6} \mathrm{H}_{2} \mathrm{Me}_{4}\right)_{2} \mathrm{Ru}_{2}\left(\mu_{2}-\mathrm{H}\right)_{3}\right]-$

(3) Bennett, M. A.; Ennett, J. P.; Gell, K. I. J. Organomet. Chem. 1982, 233, C17. 
Scheme 2. Successive Addition of $p$-Bromothiophenol to $\left[\left(\eta^{6}-\mathrm{C}_{6} \mathrm{Me}_{6}\right)_{2} \mathrm{Ru}_{2}\left(\mu_{2}-\mathrm{H}\right)_{3}\right]^{+}(\mathbf{1})$ Generating the Cations $\left[\left(\eta^{6}-\mathrm{C}_{6} \mathrm{Me}_{6}\right)_{2} \mathrm{Ru}_{2}\left(\mu_{2}-\mathrm{H}\right)_{2}\left(\mu_{2}-1,4-\mathrm{SC}_{6} \mathrm{H}_{4} \mathrm{Br}\right)\right]^{+}(\mathbf{2}),\left[\left(\eta^{6}-\mathrm{C}_{6} \mathrm{Me}_{6}\right)_{2} \mathrm{Ru}_{2}\left(\mu_{2}-\mathrm{H}\right)\left(\mu_{2}-1,4-\mathrm{SC}_{6} \mathrm{H}_{4} \mathrm{Br}\right)_{2}\right]^{+}(\mathbf{3})$, and $\left[\left(\eta^{6}-\mathrm{C}_{6} \mathrm{Me}_{6}\right)_{2} \mathrm{Ru}_{2}\left(\mu_{2}-1,4-\mathrm{SC}_{6} \mathrm{H}_{4} \mathrm{Br}\right)_{3}\right]^{+}(\mathbf{4})$ with Liberation of $\mathrm{H}_{2}$
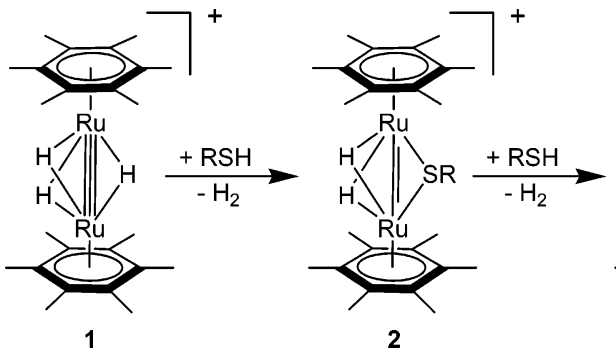

$\left[\mathrm{PF}_{6}\right]$ and $\left[\left(\eta^{6}-1,2,4,5-\mathrm{C}_{6} \mathrm{H}_{2} \mathrm{Me}_{4}\right)_{2} \mathrm{Ru}_{2}\left(\mu_{2}-\mathrm{H}\right)_{3}\right]\left[\mathrm{SO}_{3} \mathrm{CF}_{3}\right]$ were fully characterized. ${ }^{4}$

The electron deficiency of these dinuclear cations (30 e system) can be expressed by formulating either three $\mathrm{M}-\mathrm{H}-\mathrm{M}$ three-center bonds or, more conventionally, a $\mathrm{M} \equiv$ $\mathrm{M}$ triple bond being bridged by three hydrido ligands. In the case of the isoelectronic complex $\left[\left(\eta^{5}-\mathrm{C}_{5} \mathrm{Me}_{5}\right)_{2} \mathrm{Ru}_{2}\left(\mu_{2}-\right.\right.$ $\left.\mathrm{H})_{4}\right],{ }^{5}$ originally formulated with a $\mathrm{Ru} \equiv \mathrm{Ru}$ triple bond and four hydrido bridges by Suzuki et al. on the basis of the effective atomic number (EAN) rule, ab initio MO calculations showed no direct metal-metal interaction; for this reason the short ruthenium-ruthenium distance of 2.4630 $\AA$ has been accounted for by assuming four $\mathrm{Ru}-\mathrm{H}-\mathrm{Ru} 3 \mathrm{c}-$ 2e bonds. ${ }^{6}$ Despite this result of a theoretical analysis in an analogous case, the representation of the $\left[\left(\eta^{6} \text {-arene }\right)_{2} \mathrm{M}_{2}\left(\mu_{2^{-}}\right.\right.$ $\left.\mathrm{H})_{3}\right]^{+}$cations with a metal-metal triple bond is often preferred for the sake of systematics and predictability on the basis of the EAN (18-electron) rule.

The electron-deficient complexes $\left[\left(\eta^{6} \text {-arene }\right)_{2} \mathrm{Ru}_{2}\left(\mu_{2}-\mathrm{H}\right)_{3}\right]^{+}$ react with donor ligands to form complexes in various coordination modes without complete rupture of the dimetal entity. Thus, reaction of cation $\left[\left(\eta^{6}-\mathrm{C}_{6} \mathrm{Me}_{6}\right)_{2} \mathrm{Ru}_{2}\left(\mu_{2}-\mathrm{H}\right)_{3}\right]^{+}(\mathbf{1})$ with thiols leads to the successive substitution of a $\mu_{2}-\mathrm{H}$ ligand ( 1 e donor) by a $\mu_{2}-1,4-\mathrm{SC}_{6} \mathrm{H}_{4} \mathrm{Br}$ ligand ( 3 e donor) with liberation of a $\mathrm{H}_{2}$ molecule. In the case of the hexamethylbenzene derivatives and $p$-bromothiophenol, the complete series of cationic complexes $\left[\left(\eta^{6}-\mathrm{C}_{6} \mathrm{Me}_{6}\right)_{2} \mathrm{Ru}_{2}\left(\mu_{2^{-}}\right.\right.$ $\left.\mathrm{H})_{2}\left(\mu_{2}-1,4-\mathrm{SC}_{6} \mathrm{H}_{4} \mathrm{Br}\right)\right]^{+}(2),\left[\left(\eta^{6}-\mathrm{C}_{6} \mathrm{Me}_{6}\right)_{2} \mathrm{Ru}_{2}\left(\mu_{2}-\mathrm{H}\right)\left(\mu_{2}-1,4-\right.\right.$ $\left.\left.\mathrm{SC}_{6} \mathrm{H}_{4} \mathrm{Br}\right)_{2}\right]^{+}(3)$, and $\left[\left(\eta^{6}-\mathrm{C}_{6} \mathrm{Me}_{6}\right)_{2} \mathrm{Ru}_{2}\left(\mu_{2}-1,4-\mathrm{SC}_{6} \mathrm{H}_{4} \mathrm{Br}\right)_{3}\right]^{+}$ (4) has been isolated as tetrafluoroborate salts and structurally characterized, Scheme 2. ${ }^{\text {ff }, 7}$

The increase of the ruthenium-ruthenium distance in the series of 1-4 parallels the increase in the electron count of these complexes from 30 to 36 . In the context of the EAN rule, this tendency may be interpreted by a decrease in the bond order from a metal-metal triple bond in $\mathbf{1}$, to a metalmetal double bond in $\mathbf{2}$, to a metal-metal single bond in $\mathbf{3}$, and to no metal-metal bond in $\mathbf{4}$, see Table 1 .

In light of the findings for the neutral complex $\left[\left(\eta^{5}-\mathrm{C}_{5} \mathrm{H}_{5}\right)_{2-}\right.$ $\left.\mathrm{Ru}_{2}\left(\mu_{2}-\mathrm{H}\right)_{4}\right],{ }^{5}$ isoelectronic to $\mathbf{1}$, it was interesting to analyze

(4) Bennett, M. A.; Ennett, J. P. Inorg. Chim. Acta 1992, 198-200, 583.

(5) Suzuki, H.; Omori, H.; Hwan Lee, D.; Yoshida, Y.; Moro-oka, Y. Organometallics 1988, 7, 2243.

(6) (a) Koga, N.; Morokuma, K. J. Mol. Struct. 1993, 300, 181. (b) Suzuki, H.; Omori, H.; Hwan Lee, D.; Yoshida, Y.; Fukushima, M.; Tanaka, M.; Moro-oka, Y. Organometallics 1994, 13, 1129.

(7) Chérioux, F.; Therrien, B.; Süss-Fink, G. Inorg. Chim. Acta 2004, $357,834$.

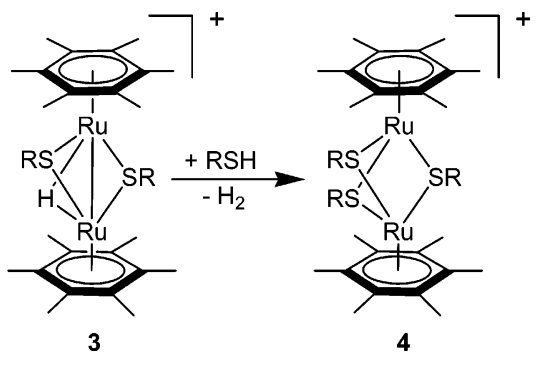

Table 1. Nature of the Ruthenium-Ruthenium Bond According to the EAN Rule

\begin{tabular}{lccc}
\hline \multicolumn{1}{c}{ complex } & $\begin{array}{c}\text { electron } \\
\text { count }\end{array}$ & $\begin{array}{c}\text { bond } \\
\text { order }\end{array}$ & $\begin{array}{c}\text { RuRu } \\
\text { distance }\end{array}$ \\
\hline$\left[\left(\eta^{6}-\mathrm{C}_{6} \mathrm{Me}_{6}\right)_{2} \mathrm{Ru}_{2}\left(\mu_{2}-\mathrm{H}\right)_{3}\right]^{+}(\mathbf{1})$ & $30 \mathrm{e}$ & $\mathrm{Ru} \equiv \mathrm{Ru}$ & $2.468 \AA$ \\
{$\left[\left(\eta^{6}-\mathrm{C}_{6} \mathrm{Me}_{6}\right)_{2} \mathrm{Ru}_{2}\left(\mu_{2}-\mathrm{H}\right)_{2}\left(\mu_{2}-1,4-\mathrm{SC}_{6} \mathrm{H}_{4} \mathrm{Br}\right)\right]^{+}(\mathbf{2})$} & $32 \mathrm{e}$ & $\mathrm{Ru}=\mathrm{Ru}$ & $2.624 \AA$ \\
{$\left[\left(\eta^{6}-\mathrm{C}_{6} \mathrm{Me}_{6}\right)_{2} \mathrm{Ru}_{2}\left(\mu_{2}-\mathrm{H}\right)\left(\mu_{2}-1,4-\mathrm{SC}_{6} \mathrm{H}_{4} \mathrm{Br}\right)_{2}\right]^{+}(\mathbf{3})$} & $34 \mathrm{e}$ & $\mathrm{Ru}-\mathrm{Ru}$ & $2.811 \AA$ \\
{$\left[\left(\eta^{6}-\mathrm{C}_{6} \mathrm{Me}_{6}\right)_{2} \mathrm{Ru}_{2}\left(\mu_{2}-1,4-\mathrm{SC}_{6} \mathrm{H}_{4} \mathrm{Br}\right)_{3}\right]^{+}(\mathbf{4})$} & $36 \mathrm{e}$ & $\mathrm{Ru} \cdots \mathrm{Ru}$ & $3.315 \AA$
\end{tabular}

complexes 1-4 from a theoretical point of view and in particular do a bond order analysis. It was the aim of this study to find out whether or not the formulation of a $\mathrm{Ru} \equiv$ $\mathrm{Ru}$ triple bond for $\mathbf{1}, \mathrm{Ru}=\mathrm{Ru}$ double bond for $2, \mathrm{Ru}-\mathrm{Ru}$ single bond for $\mathbf{3}$, and no metal-metal bond for $\mathbf{4}$, as X-ray crystallography and the electron counting rule suggest, is justified in terms of a realistic electron density in the cationic molecules.

\section{Electronic Structure Calculations}

2.1. Computational Details. DFT calculations have been carried out with the Amsterdam Density Functional (ADF) program $^{8}$ developed by Baerends and co-workers ${ }^{9}$ using the local density approximation (LDA) in the Vosko-WilkNusair parametrization. ${ }^{10}$ In addition, gradient corrections of Becke ${ }^{11}$ and Perdew ${ }^{12}$ containing nonlocal corrections for the exchange and correlation functional have been used for the energy calculations. The atomic electron configuration has been described by a triple- $\zeta$ Slater-type orbital (STO) basis set for $\mathrm{H} 1 \mathrm{~s}, \mathrm{C} 2 \mathrm{~s}$ and $2 \mathrm{p}, \mathrm{N} 2 \mathrm{~s}$ and $2 \mathrm{p}, \mathrm{O} 2 \mathrm{~s}$ and $2 \mathrm{p}$, and $\mathrm{S} 3 \mathrm{~s}$ and $3 \mathrm{p}$ augmented with a $3 \mathrm{~d}$ single- $\zeta$ polarization function for $\mathrm{C}, \mathrm{N}, \mathrm{O}$, and $\mathrm{S}$ atoms and a $2 \mathrm{p}$ single- $\zeta$ polarization function for the $\mathrm{H}$ atom. A triple- $\zeta$ STO basis set was used for $\mathrm{Ru} 4 \mathrm{~d}$ and $5 \mathrm{~s}$, augmented with a single- $\zeta$ $5 \mathrm{p}$ polarization function. The frozen-core approximation was used to treat the core shells up to $1 \mathrm{~s}$ for $\mathrm{C}, \mathrm{N}$, and $\mathrm{O}, 2 \mathrm{p}$ for $\mathrm{S}$, and $4 \mathrm{p}$ for $\mathrm{Ru}$. The geometries were optimized using the analytical gradient method implemented by Verluis and Ziegler. ${ }^{13}$ Scalar ZORA approximation ${ }^{14}$ was used to treat the relativistic effect of the core electrons on ruthenium atoms.

(8) Amsterdam Density Functional (ADF) Program, release 2.0.1; Vrije Universteit: Amsterdam, The Netherlands, 1996.

(9) (a) Baerends, E. J.; Ellis, D. E.; Ros, P. J. Chem. Phys. 1973, 2, 41. (b) Baerends, E. J.; Ros, P. Int. J. Quantum Chem. 1978, S12, 169. (c) Boerrigter, P. M.; Velde, G. Te.; Baerends, E. J. Int. J. Quantum Chem. 1988, 33, 87. (d) Velde, G. Te.; Baerends, E. J. J. Comput. Phys. 1992, 99, 84.

(10) Vosko, S. D.; Wilk, L.; Nusair, M. Can. J. Chem. 1990, 58, 1200.

(11) Becke, A. D. Phys. Rev. A 1988, 38, 3098.

(12) Perdew, J. P. Phys. Rev. B 1986, 33, 8822. 
Table 2. Selected Bond Lengths $(\AA)$ and Angles (deg) of the Optimized Structures of 1-4

\begin{tabular}{|c|c|c|c|c|c|c|c|c|}
\hline & \multicolumn{2}{|c|}{1} & \multicolumn{2}{|c|}{2} & \multicolumn{2}{|c|}{3} & \multicolumn{2}{|c|}{4} \\
\hline & calcd & exp. $^{1 \mathrm{c}}$ & calcd & exp. ${ }^{1 f}$ & calcd & exp. ${ }^{1 \mathrm{f}}$ & calcd & exp. ${ }^{7}$ \\
\hline HOMO-LUMO gap (eV) & 1.93 & & 2.01 & & 2.15 & & 2.44 & \\
\hline $\mathrm{RuRu}$ & 2.47 & 2.47 & 2.60 & 2.62 & 2.79 & 2.81 & 3.32 & 3.32 \\
\hline $\mathrm{Ru}-\mathrm{H}$ & 1.77 & 1.78 & 1.75 & 1.63 & 1.76 & 1.70 & & \\
\hline $\mathrm{Ru}-\mathrm{S}$ & & & 2.32 & 2.36 & 2.34 & 2.35 & 2.37 & 2.39 \\
\hline $\mathrm{S}-\mathrm{C}$ & & & 1.79 & $1.78^{b}$ & 1.78 & 1.79 & 1.78 & 1.80 \\
\hline $\mathrm{Ru}-\mathrm{S}-\mathrm{Ru}$ & & & 68.0 & 65.3 & 73.8 & 73.3 & 88.6 & 87.7 \\
\hline $\mathrm{Ru}-\mathrm{H}-\mathrm{Ru}$ & 88.9 & 87.7 & 95.5 & 108.1 & 103.8 & 111.6 & & \\
\hline$\Theta^{a}$ & 0.0 & & 31.3 & & 43.7 & & 0.0 & \\
\hline
\end{tabular}

${ }^{a} \Theta$ is the bending angle (deg) between the planes formed by the two benzyl rings. ${ }^{b}$ Average $\mathrm{S}-\mathrm{C}$ distances of monobridged arene- $\mathrm{Ru}-\mathrm{SR}-\mathrm{Ru}-$ arene systems. ${ }^{41}$

2.2. Geometry Optimization. The main geometrical parameters of $\mathbf{1}, \mathbf{2}, \mathbf{3}$, and $\mathbf{4}$, corresponding to energy minima as well as experimental values (X-ray structure analysis), are given in Table 2.

In going from $\mathbf{1}$ to $\mathbf{4}$, the computed $\mathrm{Ru}-\mathrm{Ru}$ distance increases from 2.47 to $3.32 \AA$, these values being in good agreement with the experimental data. For the $\mathrm{Ru}-\mathrm{H}, \mathrm{Ru}-$ $\mathrm{S}$, and $\mathrm{S}-\mathrm{C}$ bond lengths and the $\mathrm{Ru}-\mathrm{S}-\mathrm{Ru}$, and $\mathrm{Ru}-$ $\mathrm{Ru}-\mathrm{H}$ angles the agreement between computed and experimental structural data may be regarded as excellent within the range of accuracy expected at the given computational level. The highest occupied molecular orbital and lowest unoccupied molecular orbital (HOMO-LUMO) gap values from the Kohn-Sham eigenvalues of the ground-state DFT calculation are also shown; the value of $\mathbf{1}$ is increased by $0.08,0.22$, and $0.51 \mathrm{eV}$ when going to $\mathbf{2}, \mathbf{3}$, and $\mathbf{4}$, respectively, in line with the lengthening of the $R u-R u$ distances.

The $\mathrm{Ru}-\mathrm{Ru}$ distances as well as the number of $\mu_{2}-\mathrm{SC}_{6} \mathrm{H}_{4^{-}}$ $\mathrm{Br}$ bridges containing a $\pi$ system are the two main factors that influence the magnitude of the changes. These two parameters are related to the magnitude of the $\pi$-orbital interaction in the vicinity of the HOMO-LUMO orbitals. Thus, the $\mathrm{Ru}-\mathrm{Ru}$ distance increases with the value of the HOMO-LUMO gap, whereas the latter increases with the number of $\pi$ systems containing $\mu_{2}$-S-bridging ligands.

The optimized geometry of $\mathbf{2}$ and $\mathbf{3}$ exhibits the tilting of the two ring planes toward each other by, respectively, $31.3^{\circ}$ and $43.7^{\circ}$. The main difference between the computed and experimental data is observed in the angle $\mathrm{Ru}-\mathrm{H}-\mathrm{Ru}$; this is not unexpected because with X-ray diffraction it is difficult to determine accurately the position of the hydrogen atom in the bridge. In fact, the large electron density of the metal tends to place the peak of hydrogen closer to the metal.

2.3 Analysis of the Electronic Structure. According to the effective atomic number (EAN) rule, cation 1 containing three hydrido bridges should have a triple bond between the ruthenium atoms. ${ }^{15}$ To check this we carried out MO ab initio calculations. The stability of the $\mathrm{Ru}-\mathrm{H}-\mathrm{Ru}$ bridges was analyzed using an adaptation of Morokuma's decomposition of the Kohn-Sham MO's. We point out that the bond

(13) Verluis, L.; Ziegler, T. J. Chem. Phys. 1988, 22, 88.

(14) Rosa, A.; Baerends, E. J.; Van Gisbergen, S. J.; Lenthe, A. E.; Groeneveld, J. A.; Snijders, J. G. J. Am. Chem. Soc. 1999, 121, 10356.

(15) King, R. B. Encyclopedia of Inorganic Chemistry; John Wiley \& Sons Ltd.: Chichester, England, 1994. decomposition energy (BDE) $\Delta E$ between two fragments $\mathrm{A}$ and $\mathrm{B}\left(\mathrm{A}\right.$ and $\mathrm{B}$ being in the first step $\left[\left(\eta^{6}-\mathrm{C}_{6} \mathrm{Me}_{6}\right) \mathrm{Ru}\right]^{2+}$ and $\left[\left(\eta^{6}-\mathrm{C}_{6} \mathrm{Me}_{6}\right) \mathrm{Ru}\right]^{2+}$ and then in the second step $\left[\left(\eta^{6}-\mathrm{C}_{6}-\right.\right.$ $\left.\left.\mathrm{Me}_{6}\right)_{2} \mathrm{Ru}_{2}\right]^{4+}$ and $\left.\left[\mathrm{H}_{3-x}\left(1,4-\mathrm{SC}_{6} \mathrm{H}_{4} \mathrm{Br}\right)_{x}\right]^{3-}, 0 \leq x \leq 3\right)$ is divided into two main contributions $\Delta E_{\text {prep }}$ and $\Delta E_{\text {int }}$ where

$$
\Delta E=\Delta E_{\text {prep }}+\Delta E_{\text {int }}
$$

$\Delta E_{\text {prep }}$ is the energy necessary to promote the two fragments from their equilibrium geometry and electronic ground state to the geometry and electronic state that they have in the molecule. $\Delta E_{\text {int }}$ is the instantaneous interaction energy between the two fragments in the molecule. It can be divided into three main components ${ }^{16}$

$$
\Delta E_{\text {int }}=\Delta V_{\text {elst }}+\Delta E_{\text {Pauli }}+\Delta E_{\text {orb }}
$$

$\Delta V_{\text {elst }}$ corresponds to the electrostatic interaction energy between the "prepared fragments" when they are put together with unchanged electron densities at the positions they occupy in the complex $\mathrm{AB}$, giving rise to an overall density that is simply a superposition of the fragment density $\rho_{\mathrm{A}}+$ $\rho_{\mathrm{B}} . \Delta E_{\text {Pauli }}$ yields the repulsive interaction energy between fragments due to Pauli repulsion, i.e., caused by the fact that two electrons with the same spin cannot occupy an identical region in space. $\Delta V_{\text {elst }}$ and $\Delta E_{\text {Pauli }}$ are often added to a single term $\Delta E^{\circ}$, which is sometimes called the "steric energy term". The last term $\Delta E_{\text {orb }}$ is the stabilizing orbital interaction term; it is calculated in the final step of the BDE method ${ }^{17}$ when the Kohn-Sham orbitals relax to their optimal form. The orbital interaction energy $\Delta E_{\text {orb }}$ accounts for electron pair bonding, charge transfer (e.g., HOMO-LUMO interactions), and polarization (empty/occupied orbital mixing on one fragment due to the presence of another fragment); it can be decomposed into the contributions from the distinct irreducible representations $\Gamma$ of the interacting system. This energy provides direct information about the bond order.

To carry out this analysis we find it most convenient to start with the $\mathrm{d}^{6}\left[\left(\eta^{6}-\mathrm{C}_{6} \mathrm{Me}_{6}\right) \mathrm{Ru}\right]^{2+}$ fragment orbitals, interacting with the other $\left[\left(\eta^{6}-\mathrm{C}_{6} \mathrm{Me}_{6}\right) \mathrm{Ru}\right]^{2+}$ part, and the two combined $\left[\left(\eta^{6}-\mathrm{C}_{6} \mathrm{Me}_{6}\right)_{2} \mathrm{Ru}_{2}\right]^{4+}$ moieties interacting with the $\left[\mathrm{H}_{3-x}\left(1,4-\mathrm{SC}_{6} \mathrm{H}_{4} \mathrm{Br}\right)_{x}\right]^{3-}(0 \leq x \leq 3)$ bridging system. The

(16) Uddin, J.; Frenking, G. J. Am. Chem. Soc. 2001, 123, 1683.

(17) (a) Ziegler, T.; Rauk, A. Theor. Chim. Acta 1977, 46, 1. (b) Ziegler, T.; Rauk, A. Inorg. Chem. 1979, 18, 1558. (c) Ziegler, T.; Rauk, A. Inorg. Chem. 1979, 18, 1755. 


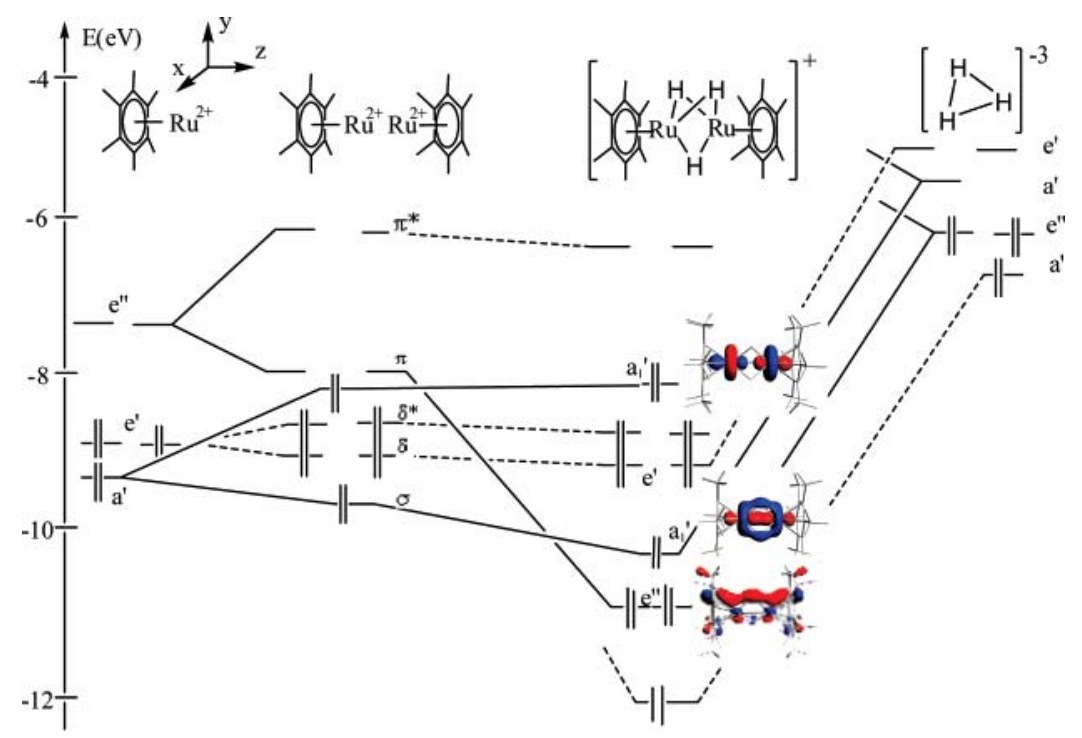

Figure 1. Orbital interaction diagram of complex 1; the orbital energy levels (eV) were calculated with GGA pw91 functional.

orbital interaction diagram of $\mathbf{1}$ is shown in Figure 1; the two ruthenium atoms are located on the $z$ axis.

This diagram shows three canonical molecular orbitals a' (d- $\sigma, \sigma$ orbital), $\mathrm{e}^{\prime}\left(\mathrm{d}-\delta\right.$, delta orbital), and $\mathrm{e}^{\prime \prime}(\mathrm{d}-\pi, \pi$ orbital) which are expected to be responsible for the bond between the two $\mathrm{Ru}$ atoms and the $\mathrm{H}$ bridges. In $\left[\left(\eta^{6}-\mathrm{C}_{6^{-}}\right.\right.$ $\left.\left.\mathrm{Me}_{6}\right)_{2} \mathrm{Ru}_{2}\right]^{4+}$, built from the two $\left[\left(\eta^{6}-\mathrm{C}_{6} \mathrm{Me}_{6}\right) \mathrm{Ru}\right]^{2+}$ fragments, both $\mathrm{d}-\sigma$ and $\mathrm{d}-\delta$ ruthenium atom orbitals are fully occupied whereas $d-\pi$ is empty; thus, in terms of orbital energy interaction (perturbation theory), the system is destabilized, because both the bonding and the antibonding orbitals are occupied. This is in agreement with the positive value of the BDE calculation: $\Delta E_{\text {int }}=9.92 \mathrm{eV}$. The molecular orbital interaction between the cationic dimer and the three anionic hydrides is shown on the right-hand side of Figure 1. We found that the composition of certain molecular orbitals (e.g., $2 \mathrm{~s} 2 \mathrm{p}$ hybrid and $3 \mathrm{~d}$ orbitals of $\mathrm{Ru}$ ) remains unchanged by going from the $\left[\left(\eta^{6}-\mathrm{C}_{6} \mathrm{Me}_{6}\right)_{2} \mathrm{Ru}_{2}\right]^{4+}$ fragment to complex 1. However, their DFT energies are found to be different as a consequence of the charge difference between the two entities. Thus, we decided to decrease the $\left[\mathrm{H}_{3}\right]^{3-} \mathrm{MO}$ energies by $-6.5 \mathrm{eV}$, which corresponds to the average of the energy differences observed. The HOMO is formed by the antibonding $\sigma^{*} \mathrm{MO}$, which involves the two $\mathrm{d}_{z^{2}}$ orbitals of the Ru atoms; the MO analysis also shows two types of strong bonding interactions: (i) the occupied $\mathrm{e}^{\prime \prime}$ orbital of the $\left[\mathrm{H}_{3}\right]^{3-}$ fragment with a vacant $\pi$ orbital of the dimer forms $\pi$ bonds, whereas (ii) the vacant $\mathrm{a}^{\prime}$ orbital of the three hydrides interacts with the equivalent $\sigma$ orbital of the dimer (the orbitals and their phases are represented). The most important contribution responsible for the stabilization of the bridge occurs via $\pi$ and $\sigma$ orbitals. The $\delta$ interaction is weak; the $\mathrm{BDE}$ calculation yields $\Delta E^{\circ}$ $=-30.88 \mathrm{eV}$ (stabilization), the orbital term being $\Delta E_{\text {orb }}=$ $-21.66 \mathrm{eV}$ (composed, respectively, of $81 \%$ and $14 \%$ of $\pi$ and $\sigma$ contribution). Thus, the bond between the two Ru atoms and $\left[\mathrm{H}_{3}\right]^{3-}$ is quite strong. From this analysis one might say that the two $\left[\left(\eta^{6}-\mathrm{C}_{6} \mathrm{Me}_{6}\right) \mathrm{Ru}\right]^{2+}$ fragments are bound by three-center two-electron hydride-bridged bonds, the direct

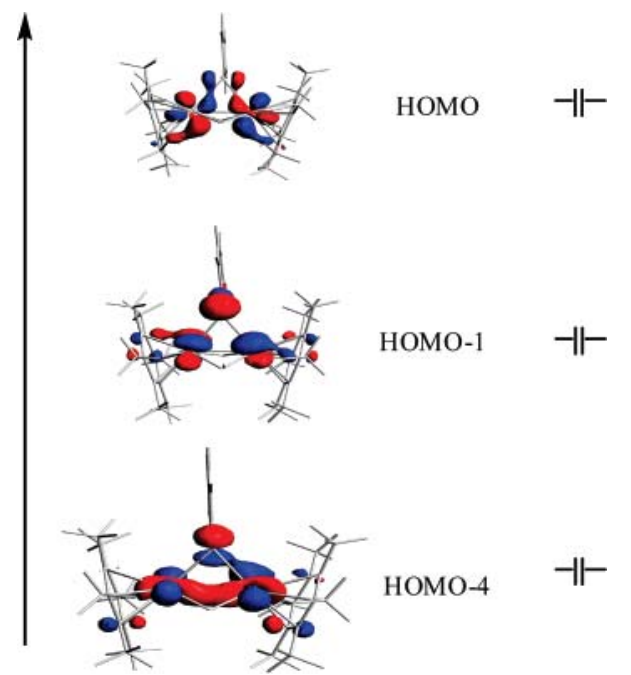

Figure 2. Qualitative orbital interactions between $\left[\mathrm{SC}_{6} \mathrm{H}_{4} \mathrm{Br}\right]^{-}$and $\left[\left(\eta^{6}-\right.\right.$ $\left.\left.\mathrm{C}_{6} \mathrm{Me}_{6}\right) \mathrm{Ru}\right]^{2+}$ fragments.

$\mathrm{Ru}-\mathrm{Ru}$ interaction is repulsive, and the three hydrides work as a "glue" to connect the repulsive fragments, the $\pi$-orbital interactions stabilizing the hydrido bridges. The importance of this $\pi$ interaction has been pointed out for $\left[\left(\eta^{5}-\mathrm{C}_{5^{-}}\right.\right.$ $\left.\left.\mathrm{Me}_{5}\right) \mathrm{Ru}\left(\mu_{2}-\mathrm{H}\right)_{4} \mathrm{Ru}\left(\eta^{5}-\mathrm{C}_{5} \mathrm{Me}_{5}\right)\right]$ by Morokuma ${ }^{6 \mathrm{a}}$ and by Dedieu et al. for $\left[\mathrm{L}_{4} \operatorname{Re}\left(\mu_{2}-\mathrm{H}\right)_{4} \mathrm{ReL}_{4}\right]\left(\mathrm{L}=\mathrm{PEt}_{2} \mathrm{Ph}\right){ }^{18}$

In complex $\mathbf{2}$, one hydrido is replaced by a $p$-bromothiophenolato bridge, which is more electron rich than the hydrido ligand; therefore, to minimize the steric effect, the $\mathrm{Ru}-\mathrm{Ru}$ bond length increases and the two $\eta^{6}-\mathrm{C}_{6} \mathrm{Me}_{6}$ ligands are tilted (Table 2). Figure 2 shows that two of the sulfur lone pair orbitals, HOMO and HOMO-4, give rise to a bonding interaction (stabilizing) with the empty orbitals of the two $\mathrm{Ru}$ (II) centers, while the third one (HOMO-1) gives rise to an antibonding interaction (destabilizing) with the filled orbitals of the $\mathrm{Ru}(\mathrm{II})$ centers. This latter interaction is responsible for the tilting of the two $\left.\left[\left(\eta^{6}-\mathrm{C}_{6} \mathrm{Me}_{6}\right) \mathrm{Ru}\right)\right]^{2+}$ moieties. From 2 to 4, the HOMO-LUMO energy gap grows

(18) Dedieu, A.; Albright, T. A.; Hoffmann, R. J. Am. Chem. Soc. 1979, 101,3141 . 
Table 3. Mayer and NLMO/NPA Bond Order Computed with TZP and TZ2P Basis Sets

\begin{tabular}{|c|c|c|c|c|c|c|c|c|}
\hline & \multicolumn{2}{|c|}{1} & \multicolumn{2}{|c|}{2} & \multicolumn{2}{|c|}{3} & \multicolumn{2}{|c|}{4} \\
\hline & TZP & TZ2P & TZP & $\mathrm{TZ2P}$ & $\overline{T Z P}$ & TZ2P & TZP & TZ2P \\
\hline & 0.90 & 0.95 & 0.60 & 0.66 & 0.34 & 0.40 & 0.06 & 0.09 \\
\hline NLMO/NPA & 0.95 & 0.93 & 0.77 & 0.70 & 0.20 & 0.18 & 0.07 & 0.06 \\
\hline
\end{tabular}

as a consequence of the increase of the HOMO stabilizing bonding interaction observed between $\left[\mathrm{SC}_{6} \mathrm{H}_{4} \mathrm{Br}\right]^{-}$and $\left[\left(\eta^{6}-\right.\right.$ $\left.\left.\mathrm{C}_{6} \mathrm{Me}_{6}\right) \mathrm{Ru}\right]^{2+}$ fragments.

\section{Bond Order and Topological Analysis}

3.1. Bond Order. In the context of simple MO theory, a number of definitions of bond order have been proposed based on the density matrix ${ }^{19}$ formed from the atomic coefficients of the occupied $\mathrm{MO}^{20}$ and natural atomic orbitals $^{21}$ (NAO). The definition which we have found particularly valuable in analyzing inorganic molecules and clusters $^{22}$ is the bond order according to Mayer ${ }^{23}$ as well as the natural localized molecular orbital ${ }^{24}$ (NLMO) summed for each natural atomic pair to give the net NPA/NLMO bond orders by Reed and Schleyer. ${ }^{25}$

The Mayer bond order is a generalization of the Wiberg ${ }^{26}$ bond order widely used in non-zero overlap theories. It is applicable to any single-determinant techniques including various semiempirical, Hartree-Fock, and density functional methods. Bond orders are particularly valuable for large and low-symmetry molecules in which the interactions between pairs of atoms may be distributed over many occupied levels.

In an effort to check the presence of bonds between the $\mathrm{Ru}$ atoms, the NLMO/NPA definition of bond order has been used. Various calculations showed that this method gives results in agreement with the chemical intuition of the bonding involving transition metals. ${ }^{27}$

From the optimized geometry we carried out both Mayer (with ADF package) and NLMO/NPA (NBO 5.0 program ${ }^{28}$ ) bond order analyses using TZP and TZ2P basis sets (in order to check the basis sets influence). The result of the calculation for the $\mathrm{Ru}-\mathrm{Ru}$ bond is summarized in Table 3 .

The results of the Mayer and NLMO/NPA bond order analyses are similar and decrease from 1 to $\mathbf{4}$ in agreement with the $\mathrm{Ru}-\mathrm{Ru}$ distances. The calculations show that bond orders are noticeably smaller as compared to the expected

(19) Glendening, E. D.; Weinhold, U. F. J. Comput. Chem. 1988, 19, 627.

(20) Albright, T. A.; Burdett, J. K.; Whangbo, M. H. Orbital Interactions in Chemistry; Wiley, New York, 1985.

(21) (a) Reed, A. E.; Weinhold, F. J. Chem. Phys. 1983, 78, 4066. (b) Reed, A. E.; Weinhold, F. J. Chem. Phys. 1985, 83, 735.

(22) (a) Bridgeman, A. J.; Cavigliasso, G.; Ireland, L. R.; Rothery, J. J. Chem. Soc., Dalton Trans. 2001, 2095. (b) Bridgeman, A. J.; Cavigliasso, G. J. Phys Chem. A 2003, 107, 4568. (c) Bridgeman, A. J.; Cavigliasso, G. Faraday Discuss. 2003, 124, 239.

(23) Mayer, I. Chem. Phys. Lett. 1983, 97, 270.

(24) Reed, A. E.; Weinhold, F. J. Chem. Phys. 1985, 83, 1736.

(25) Reed, A. E.; Schleyer, P. Inorg. Chem. 1988, 27, 3969.

(26) Wiberg, K. A. Tetrahedron 1968, 24, 1083.

(27) (a) Chang, C. H.; Boone, A. J.; Rodney J. B.; Nigel, G. J. Inorg. Chem. 2004, 43, 458. (b) Jiao, H.; Costuas, K.; Gladysz, J. A.; Halet, J. F.; Guillemot, M.; Toupet, L.; Paul, F.; Lapinte, C. J. Am. Chem. Soc. 2003, 125, 9511.

(28) Glendening, E. D.; Badenhoop, J, K.; Reed, A. E.; Carpente, J. E. Bohmann, J. A.; Morales, C. M.; Weinhold, F.; NBO 5.0; Theoretical Chemistry Institute, University of Wisconsin: Madison, WI, 2001. values for the existence of triple, double, and single bonds in complexes $\mathbf{1}, \mathbf{2}$, and $\mathbf{3}$. The NLMO analysis of $\mathbf{1}$ shows that the $\mathrm{Ru}-\mathrm{Ru}$ interaction mainly involves the contribution of the two $\mathrm{Ru}$ atoms and the three hydrides of the bridge. This is in agreement with the MO analysis discussed in the previous paragraph.

3.2. Topological Analysis: Density and ELF. Chemists' intuitive vision of bonding in molecules implicitly assumes a partition of space into adjacent regions corresponding to chemically meaningful entities such as atomic cores, bonds, and lone pairs. The aim of the topological approach to the chemical bond is the determination of such regions and their boundaries with the help of rigorous mathematical tools.

The topology of the total molecular electronic density $\rho(r)$ and the Laplacian of $\rho(r)$ [noted $\nabla^{2} \rho(r)$ ] first postulated by Bader $^{29}$ and described by atom in molecule (AIM) calculations have become useful tools for interpretation of quantum chemistry results. The maxima of $-\nabla^{2} \rho(r)$ are found to coincide with the number and relative positions of the localized electron pair domains that have been invoked in models of the Lewis electron pair. ${ }^{30}$

The topological analysis of $\rho(r)$ is performed via its gradient vector field $\nabla \rho(r)$. This field is characterized by so-called critical points, where $\nabla \rho(r)=(0,0,0)$. A differentiation between the various types of critical points is achieved through an adequate analysis of the associated Hessian matrix $H\left(\rho\left(r_{\mathrm{c}}\right)\right)$, which is a real, symmetric $3 \times 3$ matrix of the second derivatives of $\rho\left(r_{\mathrm{c}}\right)$. From the eigenvalues of $H\left(\rho\left(r_{\mathrm{c}}\right)\right)$, the different types of critical points can be characterized by their "rank" and "signature", symbolized as " $\left(r_{\mathrm{a}}, s\right)$ " where $r_{\mathrm{a}}$ is defined as the number of nonzero eigenvalues of the Hessian and $s$ is defined as the difference between the number of positive and negative nonzero eigenvalues.

In 3D space there exist four different types of nondegenerate critical points: ${ }^{31}$ attractor or local maxima of the Laplacian $(3,-3)$, repellor or local minima of the Laplacian $(3,+3)$, and saddle points $(3,+1)$ and $(3,-1)$. In the Laplacian the electronic density gives detailed information on the charge distribution. Thus, if $-\nabla^{2} \rho(r)$ is positive at $\mathrm{bcp}$, then there is a tendency for $-\nabla^{2} \rho(r)$ to concentrate at that point. ${ }^{32}$

The electron localization function (ELF) is also generally considered as a useful tool for describing the nature of the chemical bond in a wide variety of situations. ELF denoted $\eta(r)$ performs a partition of the molecular space into chemically meaningful regions. ELF was introduced by Becke and Edgecombe ${ }^{33}$ using arguments based on the conditional pair probability function. This function was

(29) a) Bader, R. F. W.; MacDougall, P. J.; Lau, C. D. H. J. Am. Chem. Soc. 1984, 106, 1594. (b) Bader, R. F. W. Atoms in molecules: A quantum theory; Oxford University Press: Oxford, U.K., 1990, (c) Bader, R. F. W.; Gillespie, R. J.; MacDougall, P. J. J Am. Chem. Soc. 1988, 110, 7329.

(30) Gillespie, R. J.; Robinson, E. A. Angew. Chem., Int. Ed. Engl. 1996, $35,795$.

(31) Popelier, P. L. A. Coord. Chem. Rev. 2000, 197, 169.

(32) Morse, P. M.; Feshbach, H. Methods of Theoretical Physics I; McGraw-Hill Book Co.: New York, 1953.

(33) Becke, A. D.; Edgecombe, K. E. J. Chem. Phys. 1990, 92, 5397. 

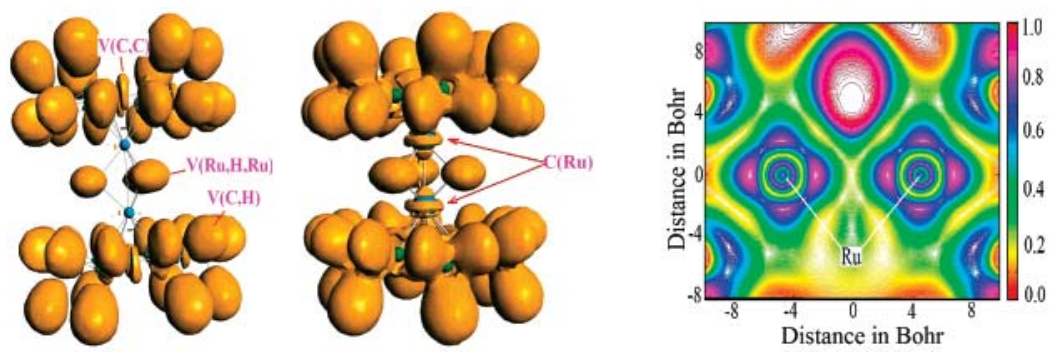

Figure 3. ELF iso-surface of compound $\mathbf{1}$ with $\eta$ values of 0.75 (left) and 0.6 (middle) and ELF values of the $\mathrm{Ru}-\mathrm{H}-\mathrm{Ru}$ plane (right).

reinterpreted by Savin et al. ${ }^{34}$ using arguments based on the excess of kinetic energy density due to the Pauli exclusion principle. The definition of ELF is given as

$$
\eta(r)=\frac{1}{1+\left(\frac{t_{-} p(r)}{t_{-} h(r)}\right)^{2}}
$$

where $t p(r)$ is the local excess kinetic energy density due to Pauli repulsion and $t h(r)$ is the kinetic energy density of a reference homogeneous electron gas of the same electron density, a value that essentially acts as a renormalization factor. Values of $\eta(r)$ range from 0 to 1 , and $\eta(r)>0.5$ usually denotes larger electron localization, i.e., a higher probability of finding electrons alone or in pairs of antiparallel spin. The value $\eta(r)=0.5$ corresponds to electron-gaslike pair probability. Basins are classified as either (1) core basins, $\mathrm{C}$ (atom), encompassing a nucleus $(Z>2)$ and core electrons, or (2) valence basins, V (atom(s)), encompassing valence shell electrons. Valence basins are further categorized by their synaptic order, which refers to the number of core basins with which they share a common boundary. A monosynaptic basin, e.g., $\mathrm{V}(\mathrm{X})$, encompasses lone pairs (not necessarily exactly $2 \mathrm{e}$ ), while a polysynaptic basin, e.g., $\mathrm{V}(\mathrm{X}$, $\mathrm{O}_{1} \ldots \mathrm{O}_{n}$ ) encompasses electrons involved in bi- or polycentric bonds. The presence of a di- or polysynaptic basin is usually indicative of a shared interaction of electrons (covalent, dative, or metallic bonds), while its absence usually denotes a closed-shell interaction ${ }^{35}$ (ionic, van der Waals, or hydrogen bond). The electronic population of a synaptic basin is obtained as the integral of the one-electron density of the basin.

ELF and AIM calculations were carried out with the TopMod series of programs. ${ }^{36} \mathrm{It}$ is noteworthy that the latter step imposes the use of a Gaussian wave function output since this feature is not yet available with ADF. Thus, using the optimized geometry from ADF, a single-point calculation has been performed with the LANL2DZ ${ }^{37}$ basis sets (its effective core potential is shape consistent and derived from reference calculations on an isolated atom within relativistic Dirac-Fock theory which includes mass-velocity and Darwin terms) and the hybrid Hartree-Fock density functional Becke3LYP ${ }^{38}$ levels using the Gaussian03 package. ${ }^{39}$

For complex 1, the charge density along the $\mathrm{Ru}-\mathrm{Ru}$ segment attains its minimum value at a bond critical point whose properties are $\rho\left(r_{\mathrm{c}}\right)=0.0164 \mathrm{au},-\nabla^{2} \rho\left(r_{\mathrm{c}}\right)=$ $-0.0784 \mathrm{au}$; the kinetic and potential energy are, respectively, 0.0167 and -0.0195 au. It is not surprising to have a positive value of the Laplacian in the bcp between the $\mathrm{Ru}$ atoms; this is frequently observed in metal-metal interaction. However, the above values are very low compared to those obtained in metal-metal interactions involving multiple bonds. ${ }^{40}$

The localization domains of $\mathbf{1}$ are displayed in Figure 3 bonded by $\eta(r)=0.75$ for the left side and $\eta(r)=0.60$ for the middle one; the monosynaptic $\mathrm{C}(\mathrm{Ru})$, and polysynaptic basins $\mathrm{V}(\mathrm{C}, \mathrm{H}), \mathrm{V}\left(\mathrm{Ru}_{1}, \mathrm{H}, \mathrm{Ru}_{2}\right)$, and $\mathrm{V}(\mathrm{C}, \mathrm{C})$ are shown. The figure is characterized by the absence of a disynaptic basin $\mathrm{V}\left(\mathrm{Ru}_{1}, \mathrm{Ru}_{2}\right)$ along $\mathrm{Ru}$ atoms; the basin population analysis indicates three times a three-center bonding situation between the two $\mathrm{Ru}$ atoms and one hydride ion $\mathrm{H}^{-}$of the bridge, $(\mathrm{V}(\mathrm{Ru}, \mathrm{H}, \mathrm{Ru}))$, where each basin accommodates approximately 1.8 e mostly located on the hydride ion $(70 \%$ of basin contribution). The right-hand side of Figure 3 displays a map of the ELF function in a plane defined by the $\mathrm{Ru}$ nuclei and one of the bridging hydride ligands,

(34) (a) Savin, A.; Nesper, R.; Wengert, S. Angew. Chem., Int. Ed. Engl. 1997, 36, 1808. (b) Kohout, M.; Savin, A. J. Comput. Chem. 1997, $18,1431$.

(35) Boily, J. F. J. Phys. Chem. A 2003, 107, 4276.

(36) Noury, S.; Krokidis, X.; Fuster, F.; Silvi, B. Comput. Chem. 1999, $23,597$.

(37) (a) Hay, P. J.; Wadt, W. R. J. Chem. Phys. 1985, 82, 270. (b) Hay, P. J.; Wadt, W. R. J. Chem. Phys. 1985, 82, 299.

(38) (a) Becke, A. D. Phys. Rev. A 1988, 38, 3098. (b) Lee, C.; Yang, W.; Parr, R. G. Phys. Rev. B 1988, 37, 785. (c) Becke, A. D. J. Chem. Phys. 1993, 98, 5648.

(39) Frisch, M. J.; Trucks, G. W.; Schlegel, H. B.; Scuseria, G. E.; Robb, M. A.; Cheeseman, J. R.; Montgomery, J. A., Jr.; Vreven, T.; Kudin, K. N.; Burant, J. C.; Millam, J. M.; Iyengar, S. S.; Tomasi, J.; Barone, V.; Mennucci, B.; Cossi, M.; Scalmani, G.; Rega, N.; Petersson, G. A.; Nakatsuji, H.; Hada, M.; Ehara, M.; Toyota, K.; Fukuda, R.; Hasegawa, J.; Ishida, M.; Nakajima, T.; Honda, Y.; Kitao, O.; Nakai, H.; Klene, M.; Li, X.; Knox, J. E.; Hratchian, H. P.; Cross, J. B.; Bakken, V.; Adamo, C.; Jaramillo, J.; Gomperts, R.; Stratmann, R. E.; Yazyev, O.; Austin, A. J.; Cammi, R.; Pomelli, C.; Ochterski, J. W.; Ayala, P. Y.; Morokuma, K.; Voth, G. A.; Salvador, P.; Dannenberg, J. J.; Zakrzewski, V. G.; Dapprich, S.; Daniels, A. D.; Strain, M. C.; Farkas, O.; Malick, D. K.; Rabuck, A. D.; Raghavachari, K.; Foresman, J. B.; Ortiz, J. V.; Cui, Q.; Baboul, A. G.; Clifford, S.; Cioslowski, J.; Stefanov, B. B.; Liu, G.; Liashenko, A.; Piskorz, P.; Komaromi, I.; Martin, R. L.; Fox, D. J.; Keith, T.; Al-Laham, M. A.; Peng, C. Y.; Nanayakkara, A.; Challacombe, M.; Gill, P. M. W.; Johnson, B.; Chen, W.; Wong, M. W.; Gonzalez, C.; Pople, J. A. Gaussian 03, Revision C.02; Gaussian, Inc.: Wallingford, CT, 2004.

(40) (a) Llusar, R.; Beltraan, A.; Andreas, J.; Fuster, F.; Silvi, B. J. Phys. Chem. A 2001, 105, 9460. (b) Feliz, M.; Llusar, R.; Andreas, J.; Berski, S.; Silvi, B. New J. Chem. 2002, 26, 844. (c) Bianchi, R.; Gervasio, G.; Marabello, D. Inorg. Chem. 2000, 39, 2360. (d) Bianchi, R.; Gervasio, G.; Marabello, D. Chem. Commun. 1998, 39, 1535. Bader, R. F. W.; Matta, C. F. Inorg. Chem. 2001, 40, 5603. (e) Penka Fowe, E.; Matija, Z.; Daul, C. Topological Analysis of Multiple Metal-Metal Bonds in series of Dinuclear Hydrides $\left(\mathrm{H}_{n} \mathrm{MMH}_{n}\right)$. Manuscript in preparation.

(41) Tschan, M. J.-L.; Therrien, B.; Chérioux, F.; Süss-Fink, G. J. Mol. Struct. 2005, 743, 177. 
showing that a local minimum is located at the $\mathrm{Ru}-\mathrm{Ru}$ midpoint distance.

\section{Conclusion}

Various approaches studied in this work (MO, BO, BDE, ELF, Laplacian) tend to show that in our series of complexes 1-4 there is no bonding interaction between the two Ru atoms. The result of molecular orbital analysis shows that the hydrogen bridges are responsible for the stability of complex 1, and additionally the value of the bond order has been found to be small, as compared to what is expected for multiple bonds. Also, ELF analysis shows that the interaction between $\mathrm{Ru}$ atoms is along the hydrogen bridge, which forms 3c-2e bonds. Replacement of a hydrido ligand by a $p$-bromothiophenolato ligand involves a structural deforma- tion of the complex (minimization of the steric effect) and lengthening of the distance between the two Ru atoms.

Although the formulation of a triple, double, or single bond in complexes $\mathbf{1 - 3}$ on the basis of the EAN rule remains a useful concept in order to rationalize bond lengths and reactivities observed, the DFT calculations performed reveal this concept to be a pure formalism.

Acknowledgment. The authors thank Prof. Bernard Silvi, Prof. Miroslav Kohout, and Prof. Carl-Wilhelm Schlaepfer for their helpful discussions and comments on this work. This work is supported by the Swiss National Science Foundation. 